\title{
Revision in the diprotodontid marsupial genus Neohelos: Systematics and biostratigraphy
}

Karen H. Black, Michael Archer, Suzanne J. Hand, and Henk Godthelp

Acta Palaeontologica Polonica 58 (4), 2013: 679-706 doi: http://dx.doi.org/10.4202/app.2012.0001

Neohelos is a geographically and temporally widespread genus of Cenozoic diprotodontid marsupials commonly used to biocorrelate otherwise undated Australian fossil deposits. Here, we revise the genus and describe two new species from the Riversleigh World Heritage Area of northwestern Queensland. Neohelos solus sp. nov. is a small, relatively abundant, plesiomorphic form, while the rarer, larger Neohelos davidridei sp. nov. is the most derived species of the genus with an upper premolar morphology that is structurally antecedant to members of the Late Miocene genus Kolopsis. Additional material of Neohelos tirarensis and Neohelos stirtoni is described. A chronological morphocline is evidenced by a gradual change in morphology accompanied by an increase in size from $\mathrm{Ne}$. tirarensis through Ne. stirtoni to Ne. davidridei , and is generally consistent with the biostratigraphic distribution of Neohelos species throughout Riversleigh's faunal zones A to D. Stage of evolution biocorrelation of Neohelos species confirms that some of Riversleigh's Faunal Zone A deposits are Late Oligocene in age and predate the Wipajiri Formation of South Australia. Strong faunal correlations exist between Riversleigh's topographically low to middle Faunal Zone $\mathrm{C}$ deposits and the Northern Territory's Middle Miocene Bullock Creek Local Fauna. The presence of the highly derived $N$. davidridei in the Jaw Junction Local Fauna of Riversleigh's Upper Faunal Zone C suggests a later Middle Miocene (post-Bullock Creek) age for this deposit.

Key words: Mammalia, Marsupialia, Vombatomorphia, Diprotodontidae, Zygomaturinae, biocorrelation, systematics, Oligocene, Miocene, Riversleigh, Australia.

Karen H. Black [k.black@unsw.edu.au], Michael Archer [ㅍ.archer@unsw.edu.au],

Suzanne J. Hand [s.hand@unsw.edu.au] and Henk Godthelp [h.godthelp@unsw.edu.au], School of Biological, Earth \& Environmental Sciences, University of New South Wales, Sydney, NSW, Australia, 2052. 
This is an open-access article distributed under the terms of the Creative Commons

Attribution License (for details please see creativecommons.org), which permits unrestricted use, distribution, and reproduction in any medium, provided the original author and source are credited.

Forif Full text $(1,002.0 \mathrm{kB})$ 